\title{
Sociocultural System of Tambak Lorok Community, Tanjung Mas, Semarang City
}

\author{
Nurdien H. Kistanto \\ nhkistato@gmail.com \\ Faculty of Humanities, Diponegoro University \\ Jl. Prof Soedarto, Tembalang, Semarang 50275, Indonesia
}

\begin{abstract}
This paper analyzes Tambak Lorok community as an entity group of people who forms patterns of activity and relationships between citizens. A set of patterns of activity and interrelationship is primarily organized through and in the form of livelihood and occupations. In accordance with the natural environment, namely coastal areas, livelihood and employment of many people of Tambak Lorok are fishing, carried out by fishermen as husbands or household heads, and accompanying activities such as processing and selling of marine products, mainly fish, by female fish processors and/or fish traders.This study aims to generate an analysis of the types of livelihood and employment, profile of the actors, and patterns of functional relationships in the socio-cultural system of the community.
\end{abstract}

Keywords: Sociocultural system, livelihood, fishermen, fish traders, urban coastal area, Semarang City.

\section{Introduction}

The area of Tambak Lorok, Tanjung Mas Village, East Semarang District, Semarang City, is a distinctive and interesting region, in the urban coastal environment, with communities that run livelihood and work as fishermen and activities relating to the capture, processing, and trade of fish and seafood, carried out by processors and/or fish traders. The importance of the area and community of Tambak Lorok is growing in the region since some years ago was built to become the area of Wisata Kampung Bahari (Marine Tourist Kampong) as a project with 3 (three) focuses namely (1) The improvement of Tambakmulyo Road, of 738 meters length, (2) The development of green open spaces, and (3) the development of traditional fish markets. The budget used reached 47 billion rupiah that was completed by the end of March 2019.

This study generates analysis of the types of livelihood and occupation, profiles of the actors of livelihood and occupation, functional and socio-cultural relationships of the actors of livelihood and occupation. The analysis was conducted to produce field descriptions of the people who work as fishermen and fish traders, with the main concern on the livelihood system and coastal community occupation of Tambak Lorok.

\section{The Tambak Lorok Sociocultural System}

The sociocultural system can be understood as "human population viewed... in its ecological context and as one of the many subsystems of a larger ecological system" as well as "the human population that is seen in his ecological relationships and as one of the many 
subsystems of the larger ecologic system" [1] [2] [3]. The term "socio-cultural system" includes three concepts, namely society, culture, and system. Society is a number of organisms of the same species, namely humans, that are interdependent. Culture is the learning outcomes of patterned behavior that are carried out jointly by the citizens, along with material and immaterial products from the human behavior. The words "society" and "culture" combined together form the word "socio-cultural;" while the word "system" is a "collection of interconnected or interconnected parts to function as a whole unit" [2]. The term socio-cultural system is used to address society from cultural perspectives and socio-cultural analysis [3] [4] [5]. In Tambak Lorok's socio-cultural system, the residents of Tambak Lorok run activities and interact with each other with patterned functions so that it becomes a cultural building consisting of elements that become a way of life of the community. Culture or way of life in the socio-cultural system includes tangible cultural elements in the form of material or manmade objects and intangible ones such as values and norms, ideas, ideologies, and thoughts, [3] [4] [8] run by communities in Tambak Lorok. Marvin Harris [5] outlines the universal structure of the socio-cultural systems, namely "infrastructure" (production and population), "structure" (relating to human behavior, such as corporations, political organisations, hierarchies or levels in society), and "superstructure" (i.e. mental, such as belief, values, norms) [6] [7] [5] [9]. In the concept of Koentjaraningrat [9], culture in the socio-cultural system contains 7 (seven) universal elements, namely 1. Livelihood System, 2. Knowledge System, 3. Technology and equipment systems, 4. Society and social organizational system, 5. Religion and belief system, 6. Arts, and 7. Language. The seven elements of the culture are also present and become the way of life of the people of Tambak Lorok.

The research of the Tambak Lorok socio-cultural system focuses on the livelihood system, which contains the activities of the livelihood by the Tambak Lorok community in the coastal area. Very closely related to the coastal environment, the most important livelihood is catching or hunting, collecting, processing and trading the sea-results, especially fish. This study analyzes the life of fishermen, as actors who seek or hunt, and collect the results of the sea, especially fish; and fish processors and traders, which process and trade the sea-resources, especially fish [10] [11] [12] [13] [14] [15] [16] [17] [18].

\section{Fishermen, Work Schedule and Income}

Tambak Lorok fishing village is a coastal area that is inhabited and accessed by about 400 (four hundred) fishermen. The fishermen were made up of people who had inhabited the village for decades on a hereditary basis, and newcomers, called the fishermen of Adon, who came from various other areas on the north coast of Central Java, such as Demak, Jepara, and Kendal. Some of these migrants live on board, rent a room, or board, in various aisles of the surrounding complex (Rukun Tetangga). Fishermen of Tambak Lorok are considered small and medium-sized fishermen.

Fishermen arrange work schedules and working relationships in carrying out their livelihoods. Fishermen are also associated with the problems of the capture equipment and the capture technology. In addition, as in the fisherman communities on the other areas of north coast of Java, fishermen of Tambak Lorok can also be divided into levels that are based on capital ownership and capture equipment. In general they are between 20 to 60 years of age.

Some fishermen of Tambak Lorok work catching fish in the sea only between 3-4 hours, such as Supaat, 33 years old, who states that he set out to work between 4-5 a.m. and return between the hours of 7-8 in the same morning, roundtrip, to and from the sea is about 2 miles or $3 \mathrm{~km}$. But before departing he should prepare the departure of work, so that the 
schedule can be more than 4 hours per day. I met and interviewed Supaat on Sunday (July 28, 2019) at the sugarcane-ice stall, after attending the ceremony and celebration of "Sedekah Laut and Bumi" (Sea and Earth Alms) at the end of the pier to take a boat to the sea to throw the buffalo head into the middle of the sea. Accompanied by his wife named Febri Ratnadewi, 28 years old, who worked as a store-keeper of household appliances such as buckets and school tools at MT Haryono Street, and his son named Mohamad Bisri, 9 years, grade 3 Elementary School, Supaat said starting became a fisherman following his father, after graduating elementary school, about 20 years ago; while his father is no longer at sea, because in the age of 60s, he feels too old to stay working as a fisherman. Supaat uses a crab fishing boat and a cage that is called the eco-friendly equipment. To leave for the sea, Supaat postponed until the fishermen of Sodo, who use a device of bamboo sodo with 1/2 to 2 inches hole, which he called eco-unfriendly and forbidden fish net, returned from the sea. Fishermen of Bamboo Sodo, work in the sea for a longer time, depart for the sea at 5 p.m. and go home from the sea at 4 a.m. in the following morning. Supaat called Sodo fishermen sweeping all kinds of fish and shrimp, large and small without size, in the shallow sea, depth of 1-2 meters, and tend to be "greedy." Fisherman using fishing nets which are environmentally friendly catching crabs, such as Supaat, feel better mengalah, to give in.

As a fisherman, Supaat admitted erratic income. "Yesterday (Saturday, 27 July 2019) only got the result of Rp. 80,000 from the sale of crabs and choking. The previous day, can even only had the result of Rp. 40,000. " According to Supaat, the earning of fishermen "is very uncertain, can be in the range of Rp. 0 to Rp. 200,000. It is rare to obtain results up to Rp. 400,000 or Rp. 500,000. All depends on the goodness of Nature, depending on the giving of Allah Subhanahu wa Ta'ala to fishermen. For example, in mid-June 2019, I got the result of Rp. 200,000 gross, from the sale of $2 \mathrm{~kg}$ of blue crabs (rajungan), $1 \mathrm{~kg}$ of red crabs (kepiting), and a number of rucah fish (a mixture of several types of fish). Such results were cut by 1.5 liters of gasoline Rp. 12,000, bread for breakfast Rp. 2000 and 1 pack of cigarette Rp. 22,500. I take Rp. 50,000 before I leave all on my wife to cook and the tuition of kid school."

\section{Working Relationship, Fish Traders and Fish Market}

Landing from the sea, Supaat is awaited by the fish traders who want to buy the catch, the crabs, and a rucah, which contains various types of fish. The most important business relationship of fishermen is with the processors and/or traders of fish, who buy the catch for sale in the market, both in the area fish market and other fish markets in the city of Semarang. Depending on the big or little size of the crabs or the fish, if the trader buy crabs from fishermen of Rp. $50.000 / \mathrm{kg}$, she will sell it to Rp. $70,000 / \mathrm{kg}$. While the price is very varied depending on the type and size of fish purchased from fishermen. Supaat sell the results directly to the fish traders, not through the Fish Auction Place (TPI), because the catch is too little. Only catches of fish, crabs, and shrimps or prawns that reach the weight of 1 quintal or more are sold through auctions in the TPI that take place at 7 to $11 \mathrm{am}$. Fishermen of Adon or fishermen who come other areas such as from Demak, Jepara and Kendal with larger boats, handed the catch on the TPI management to be auctioned that morning as well. The fish traders from the fish markets in Semarang since 6 a.m. have come to join the auction, buying fish and other sea-catches for resale in their respective markets.

The new Tambak Lorok Fish Market, two-storey, was inaugurated at the end of March 2019. On the first floor there are 72 stalls sized of $2 \times 2 \mathrm{~m}$, arranged in 6 lines, with each line containing 12 stalls, and only 63 new stalls occupied by the traders, the rest of 9 stalls are still empty even though there are traders who rent it. Of the 63 traders, 9 traders do not sell fish but 
1 sells meat and chicken, 1 sells cut-chicken, 1 sells meat, 1 sells cut-chicken and smoked fish, 1 sells chicken and quail eggs, and 3 sell chicken and nine staples of food (sembilan bahan pokok pangan or sembako). In addition, there are 5 fish traders selling outside the market building but still inside the market complex and 5 merchants held their trades outside the market complex, on the roadside. The 2 nd floor of the fish market is an open space without a partition of stalls, occupied by the sellers of vegetables and fruits, which have not even counted the fingers of the 2 hands.

Merchant schedules vary, some start selling at 6 or 7 a.m. to 1 or 2 noon, some are just coming at 2 noon when some traders want to go home, but some are selling until 4, 5, and 6 p.m.. The vendors who occupy the stalls in the fish market are subject to rent Rp. 3500/day, security charge Rp. 5000/day, and cleaning-waste charge Rp. 2000/day. The merchants in the fish market sell fresh fish and other sea products directly from newly landed fishermen or from $T P I$, through auctions.

\section{Conclusion}

In closing, I would like to state that Tambak Lorok community has formed its cultural values for a long and continuing time, by running coastal livelihood and occupation, and with this by shaping patterns of interrelations among the cultural actors of sea product enterprises such as the interrelations of the fishermen and the fish traders, whether using direct, person-to-person transactions, or indirect transactions through the auction place. By these behavioral ideas as well as practices, Tambak Lorok community has developed their ways of life, their cultural elements, within their sociocultural system since long long time ago.

\section{References}

[1]. Nanda, Serena. Cultural Anthropology. Second Edition. Stamford, Connecticut: Wadsworth Publishing Company. (1984)

[2]. Kauffman, Draper L. Systems One: An Introduction to Systems Thinking. Minneapolis, MN: Future Systems Inc. (1980)

[3]. Scupin, Raymond. Cultural Anthropology: A Global Perspective. Boston: Pearson. Culture, pp. 41-57; Analyzing Sociocultural Systems, pp. 128-142. (2016)

[4]. Gharajedaghi, Jamshid. Systems Thinking, Managing Chaos and Complexity. 3rd edition. Boston: Elsevier (2011)

[5]. Harris, Marvin. Cultural Materialism: The Struggle for a Science of Culture. New York: Random House (1979)

[6]. Elwell, Frank W."Harris on the Universal Structure of Society," Retrieved 9 July 2019, http://www.faculty.rsu.edu/-felwell/Theorists/Essays/Harris1.htm. (2013a)

[7]. Elwell, Frank W. Sociocultural Systems. Principles of Structure and Change. Vancouver: UBC Press (2013b).

[8]. Giddens, Anthony. Sociology. Cambridge: Polity Press, pp. 31-32. (1991).

[9]. Koentjaraningrat. Kebudayaan, Mentalitas dan Pembangunan. Jakarta: Gramedia (1974)

[10]. Wahyudin, Yudi. 5 December 2003. "Sistem Sosial Ekonomi dan Budaya Masyarakat Pesisir." Workshop Paper on Management of Water Conservation Area/Pengelolaan Kawasan Konservasi Persairan. Bogor Agricultural University. Upload October (2015). 
[11]. Massadun dan Putri Nurpratiwi. April. Kajian Penyebab Kemiskinan Masyarakat Nelayan Tambak Lorok. Journal of Regional and City Planning, Vol. 27, No. 1, pp. 4967. (2016)

[12]. Susiana, Rini. Juni Budaya Pesisir: Perilaku Konsumtif Masyarakat Tambaklorok, Kelurahan Tanjung Mas, Kecamatan Semarang Utara, Kota Semarang. Sabda - Journal of Cultural Analysis, Vol. 13, No. 1, pp. 59-66. (2018).

[13]. Hartomo, Giri. Jurnalis. Sabtu, 23 Februari 2019. Menengok Kawasan Nelayan Tambak Lorok Semarang yang Didatangi Presiden Jokowi. Economy. Economy.okezone.com.

[14]. Baihaqi. 26 Maret 2019. Hendi Ingin Tambaklorok Jadi Sentra Kuliner Seafood, Kenyataan di Lapangan Justru Berkebalikan. Jatengtoday.com.

[15]. Indonesia, Pasar. 25-01-2017. Pasar Tambak Lorok: Berbagai Ikan ada di sini, serta menjadi matapencaharian nelayan. Pasarindonesiablog.wordpress.com.

[16]. Rizqi, Alif Nazzala. 22 Oktober 2018. Pemprov Jateng Rancang Kampung Bahari Terintegrasi TPI. Semarang.solopos.com.

[17]. Tempo.co. Selasa, 6April 2010. Nelayan Semarang Ingin Retribusi Tetap Diberlakukan. National.tempo.co.

[18]. Nurdin, Nazar. Selasa, 2 Desember 2014. Jokowi Janji Segera Bangun Tempat Pelelangan Ikan di Kampung Nelayan Semarang. Amp.kompas.com.

[19]. Republika.co.id. Tuesday, 26 Mar 2019. Pasar Tambaklorok Bakal Jadi Pusat Kuliner Olahan Ikan Segar. M.republika.co.id.

[20]. Fama, Achmad. Komunitas Masyarakat Pesisir di Tambak Lorok, Semarang, Jurnal Kajian Kebudayaan Sabda - Journal of Cultural Analysis, Vol. 11, No. 2 (2016)

[21]. Kusnadi. Pembangunan Wilayah Pesisir Terpadu. Yogyakarta: Graha Ilmu (2015) 